\title{
Actor, Structural, and Empirical Dimensions of Forest Governance Issues in Riau Province
}

\author{
Ranggi Ade Febrian ${ }^{1}$, Budi Mulianto ${ }^{2}$ \\ $\frac{\left\{\text { ranggi.ip@soc.uir.ac.id }{ }^{1}\right\}}{\text { Riau Islamic University }}$
}

\begin{abstract}
Forests as development capital have real benefits for life, both ecological, socio-cultural and economic benefits, balanced and dynamic. For that, the forest must be managed and managed, protected and utilized sustainably for the welfare of society, both present, and future generations. The problem, in the year 2013, recorded the total extent of forest area damage of 1,536,653.99 ha or about $36.74 \%$ of the total forest area of Riau Province. This condition is caused by unclear borders of forest area in the field because it has been lost and damaged, weak supervision and law enforcement. On the other hand, the ability of forest and critical land rehabilitation tends to decrease, since the forests and critical lands that will be rehabilitated have been controlled by irresponsible parties. In 2009, forest rehabilitation and critical land covering 275.28 thousand hectares fell to 95 thousand hectares by 20 . This paper looks from the aspects of forest governance, using the perspective of actors, structural, and empirical dimensions. It can be concluded that the effort of subscribing forest crime cases and improvement of forest governance that has been done by the government is still not showing optimum result based on indications such as smoke haze, no significant degradation and deforestation rate, law enforcement process which still lack the ability to give deterrent effect to the perpetrator especially mastermind of illegal logging perpetrator.
\end{abstract}

Keywords: Actor, Structural, Empirical, Forest Governance

\section{Introduction}

Forest is an integrated ecosystem in the form of land that contains sources biological power that is dominated by the natural environment, which is inseparable from one another. Forest areas are certain areas designated and or determined by the Government to maintain their existence as permanent forests Faisal, Aksa, \& Samad [1], and this study looks at trends and damage data in the forestry sector in Riau Province from the perspective of collaborative governance.

The emergence of opinion settings related to the damage that occurred and this became the evaluation material related to cases of the forestry sector in Province Riau. In this paper can also see the trend of forestry sector problems that occurred in Riau Province early in the case of illegal logging, then developed in the legal licensing process but the permit was obtained in illegal ways. In the context of permits obtained by illegal and illegal means, there is corruption and collusion.

From this research, can be viewed and mapped forest mastery. Although permits that come out a lot but who mastered only a few people. The amount of area given is also very large. Jikalahari records industrial tree plant permits alone reaching 2.1 million hectares. The other 
side of the community around the concession is in fact still in a poor state and the village remains behind. This means that the existence of the concession does not have a direct impact on the welfare of the community. Then besides HTI permits, the plantation also followed with a fantastic extent of 2.6 million hectares. Sure it looks good. But again from the vast plantation area is also only controlled by a handful of people. This clearly shows the poor forestry in Riau as a miniature of Indonesia.

This research is viewed from the perspective of forest governance by using the concept of governance introduced by Hayden [2]. This concept has advantages over other concepts as it more comprehensively identifies large dimensions in the context of governance, ie the dimensions of actors, structural dimensions, and empirical dimensions. The concept of governance according to Hayden [2] serve as the initial foundation to explore the problems of forestry sector development in Riau Province.

\section{Method}

The research method used in this research is a qualitative research method with phenomenology approach. This approach is used to get the right data related to damage to the forest sector correctly and simply. The phenomenological approach introduced by Husserl [3], this approach goes from the truth of the phenomenon, as it seems to be Ferguson [4]. An apparently apparent phenomenon of self-contained reflection because it appears to be a transcendental meaningful object [5]. Therefore, to obtain the essence of truth, it must break through the visible phenomenon [6].

\section{Result and Discussion}

\subsection{Dimension of Actor}

In forestry governance in Riau Province is strongly influenced by the dimensions of actors, especially in corporate crime. The result of research and investigation of in the last ten years, finding the problem of illegal logging and forestry corruption is still related to the basic question that has not been completed by the country; RTRW is incomplete, overlapping licensing and inauguration of boundaries of the unfinished forest. Essentially forest governance is chaotic. As a result, forestry crime and forestry corruption emerged to the detriment of state finances, the suffering of people around the forest and the destruction of forests and the environment.

Discloses forestry problems in Riau Province has now shifted from illegal logging to forest encroachment and land tenure. This activity caused forest destruction, caused critical land, and for almost 18 years Riau Province faced a forest fire that caused smoke haze every year [7]. Another problem is the completion of the Riau Regional Spatial Plan (RTRW) which has not been ratified until 2015 by the Central Government.

The findings of Jikalahari, reinforced by KPK Review and Constitutional Court Decision. According to the KPK, the complexity of forestry and natural resource spatial problems, such as overlapping regulations and regulations leading to conflict, has resulted in not only the state's economic losses but also ecological and social costs that have not been counted yet. The result of "KPK Integrity Survey in Public Sector" found that there is only one central agency that obtains the integrity value below 6, that is the Ministry of Forestry.

The Constitutional Court of the Republic of Indonesia decides the case of judicial review against Article 1 number 3 of Law Number 41 the Year 1999 jo. The essence of the verdict, materially demonstrating the designation of forest areas without involving stakeholders, is an 
authoritarian act and the Confirmation of forest areas should pay attention to RTRW and individual rights Survey and the decision of the KPK and the Constitutional Court confirmed the findings.

Jikalahari that the problem of bad forestry governance because the Minister of Forestry issued a policy more pro-corporate and did not pay attention to the rights of people living and living inside and outside the forest area. Actual facts, latent conflicts, and ecological damage are derived from the Minister of Forestry's policy. The case of Pulau Padang, one of the most prominent cases of Menhut as a key actor is not careful in issuing permits.

In addition, the Illog Riau SP3 Case of 2008 and five forestry corruption suspects in Siak and Pelalawan illustrate clearly the corporation is the main actor of the bribe to permit the ban on natural cutting in the area of plantation forest, can be felled. From illegal by giving some money to State officials, it could be legal. Why do corporations deliberately conduct such illegal practices? Due to huge profits: Rp 1.994 trillion (SP3 Illog Riau), and Rp 3 Trillion (forestry corruption). The Forest Crimes Mode, learning from Case Studies in Riau related SP3 and the Siak-PelalawanKosupsi Case: (1) The directors of the corporation Establish good relationships with officials (Central and local, including their immediate families) by providing gifts, physical and non-physical facilities, support in the election process, promotion and official mutations, official assistance and other forms of charity. Building this good relationship cannot be separated from local cultural and political factors. If good relationships have been established through family ties and parochial allegiance, public officials find it difficult to deny requests for special treatment from perpetrators, since denial is defined as a denial of traditional obligations.

(2) Bribe state officials to obtain permits and smooth the process (3) Cut down in a protectted area, (4) Logging without permission or documents (5) Cutting more than the quota (6) Using fake permissions or permits that have died (7) Cut down in HGU areas that have not been granted permission to release the area.

(8) Preparation and widening of corridor roads that have not been licensed for borrowing or disposal of the area. (9) Mixing Illegal Timber (without a permit or problem permit, including protected timber) with legal timber: on wood buildup, transportation process, the wood buildup in industry, mixing during production.

The results of Jikalahari's review with Riau corruption trial against the verdict of corruption convicting judges in Pelalawan and Siak and SP3 Illog Riau also found there were allegations of money laundering in cases of forest crime and corruption. Briefly referring to Law No. 8 of 2012 on Prevention and Eradication of Money Laundering Crimes, article 2 paragraph 1 states Results of criminal acts are assets acquired from criminal acts, three of them (corruption, bribery and in the field of forestry), carried out by the actor corporations have an impact on the destruction of forest management in Riau Province.

\subsection{Structural Dimensions}

Forest sector governance seen from the structural dimension describes the use of authority by the government. The forestry sector of Riau Province is influenced by the regional authority in the spatial planning of the RTRW. In Law No. 26 the Year 2007 on Spatial Planning, RTRWP preparation is done by referring to RTRWN (National Spatial Plan), then RTRWK (Spatial Plan of Regency / City) also must refer to RTRWP. It is intended for synchronization of Development between National, Provincial and District / City levels.

The TOWN is prepared for 25 Years, RTRWP for 15 Years and RTRWK for 10 Years. Revisions or Review can be made every 5 Years. Revision or Review aims to reconcile various regional, national and international policy developments that may arise on the way. 
The importance of Spatial Planning means that every development policy made by the Provincial and Regency / City Governments is not out of the existing spatial use directives.

Implicitly Spatial also contains about the division of authority between the Central Government and the Regions, either in the Determination / Change of the Status of Forest Areas, the granting of allocations of space for Investment and Development of Settlements / Urban and Rural, and others. If viewed from the perspective of Ecological Spatial also serves to provide certainty for the protection of the area, ecosystems, and habitats that have high ecological value. Then the meaning will be wider when viewed from the Perspective of Social, Economy, Culture, and Politics.

The issuance of Law No. 26 of 2007 followed by the issuance of Government Regulation No. 26/2008 on National Spatial Planning in the National Region Spatial Map is determined as 3.376 .000 ha as the protected area or $37.61 \%$ of a total land area of $8,975,784$ ha. Of the total area designated as a protected area, an area of 1,060,000 ha of which already has a permit HTI and Plantation area of 353,800 ha. This space utilization permit is granted either by the Minister, the Governor, or the Regent.

The momentum of regional autonomy that had given authority to the Governor and Regent / Mayor in issuing Forest Timber Plantation Utilization Business Permit (IUPHHK-HT) or Industrial Timber Plantation Permit (HTI) seems to be highly utilized by both companies, not least in Riau. So that the Natural Forest Damage is getting out of control and increasing. This condition then encourages the central government to revoke the Authority of the Governor and Regent / Mayor in issuing IUPHHK-HT. However, the authority was misused by the Head of Region as a key actor of forestry sector development in Riau Province.

\subsection{Empirical Dimension}

The empirical dimension is seen from responsive and responsible leadership indicators. Leadership is responsive and points to the attitude of political leaders in their role as the public trust. Indicators include the level of respect for leaders to the public, the level of openness of public policymaking and the level of obedience to the rule of law.

Destruction of public confidence in leadership indicators due to the Commission determined former Riau Governor Rusli Zainal in July 2013 who was indicted On the basis of approval of BKUPHHKHT which is not its authority. The approval of this permit has enriched nine companies or cost the state finances a total of Rp 264 billion. The total state loss of $\mathrm{Rp}$ 264 billion in KPK's calculation is still unfair to Ecological. KPK should approach EcologicalEconomical calculation on the case of defendant Rusli Zainal.

The destruction of natural forests is not only calculated on the basis of lost natural timber stands but more than that, ecological damage to give a sense of justice to the natural forests and environment that have been undermined by paper industry companies. Specifically for the indictment of forest corruption, Rusli Zainal is threatened with Article 2 paragraph (1) and Article 3 jo Article 18 of Law Number 31 Year 1999 concerning the Eradication of Corruption as amended by Act Number 20 of 2001 on Amendment to Law - Law Number 31 Year 1999 regarding Corruption Eradication jo Article 55 paragraph (1) ke1 Penal Code in conjunction with Article 65 paragraph (1) of the Criminal Code.

Convict HM Rusli Zainal (Governor of Riau) was convicted by the Corruption Court of Pekanbaru Corruption Court for 14 years in prison, a fine of Rp 1 Billion for committing a criminal act of corruption together. Consequences his actions have been detrimental to the State's finances or profitable corporation worth $\mathrm{Rp} 265,912,366,170.20$ at least Rp 265 billion for issuing URKT / RKT which is not his authority as Governor of Riau for 9 corporations in 2004. 
The lack of public confidence in forest governance in Riau Province is due to the impact of forest fires by the companies that caused haze disaster in Riau Province. Throughout JuneOctober 2015, World Bank4 released a karhutla area in Riau at 139,000 ha, a loss of 19 trillion. More than 97,139 smoke pollution victims suffered acute respiratory infections 81,514 people, 1,305 pneumonia, 3,744 asthma, eye irritation 4,677 people, skin irritation 5,899 people5 and 5 died. Slow government saves people smog pollution, from such a huge "disaster", the Riau people carried out litigation efforts in both field investigations, calls to the government, solidarity actions to monitoring cases of forest and land fires held in court. This is the description of forestry governance in Riau Province which is seen from the dimensions of actors, structures, and empirical shows the weak role of government to compel the corporation to play its role according to regulation and ecology.

\section{Conclusion}

Forest sector governance in Riau Province cannot be separated from law enforcement. The dimensions of the actor become very dominant affect the structural and empirical dimensions. Because the actor is involved in the law enforcement process related to forest crime case. In fact, it is not impossible to add a row of government officials involved in Riau see many similarities in licensing cases.

This situation clearly has tarnished the Riau province's dignity and dignity which is identical with Malay and religious values. Looking at the actors who have been dragged into forestry crime cases in Riau, it can be deduced that the estuary of these cases is an interruption of existing forestry policy so that every government official can articulate policies with different perceptions. Whereas the understanding of a policy should be the same so as not to cause confusion in implementing it. Of course, if there are no improvements to the current policies will increase the row of Riau's best children who are dragged to the green table. Attempts to subscribe to forestry crime cases and forest governance improvements that have been done by the government are still not showing optimum results based on indications such as smoke haze, no significant degradation and deforestation rate, law enforcement process that still lacks the ability to provide deterrent effect to the perpetrators, especially the mastermind of the perpetrators of illegal logging crime, there is even a strong indication that money laundering has occurred.

\section{References}

[1] F. Faisal, A. Aksa, and M. Samad, "Koordinasi Pemerintah Daerah dengan Lembaga Adat dalam Pelestarian Hutan Adat di Kawasan Adat Ammatoa Kajang Kabupaten Bulukumba," Otoritas J. Ilmu Pemerintah., vol. 2, no. 2, 2012.

[2] G. Hayden, Governance and The Study of Politics: Governance and Politics in Africa. Boulder: Colorado, 2000.

[3] E. Husserl, "The crisis of European sciences and transcendental phenomenology: An introduction to phenomenological philosophy," Northwest. Univ. Press, vol. 5, 1970.

[4] H. Ferguson, Phenomenology and social theory. Philpapers, 2001.

[5] S. Basrowi, Metode Penelitian kualitatif perspektif mikro. Surabaya: Insan Cendekian, 2002. 
[6] M. Waters, Modern Sociological Theory. Thousand Oaks, London: Sage Publications, 1994.

[7] R. A. Febrian, “Akuntabilitas Kebijakan Sektor Kehutanan Di Provinsi Riau.” 2015. 